\title{
Authentication of Iceland Moss (Cetraria islandica) by UPLC-QToF-MS chemical profiling and DNA barcoding
}

Article

Accepted Version

Creative Commons: Attribution-Noncommercial-No Derivative Works 4.0

Xu, M., Heidmarsson, S., Thorsteinsdottir, M., Kreuzer, M., Hawkins, J., Omarsdottir, S. and Olafsdottir, E. S. (2018) Authentication of Iceland Moss (Cetraria islandica) by UPLCQToF-MS chemical profiling and DNA barcoding. Food Chemistry, 245. pp. 989-996. ISSN 0308-8146 doi:

https://doi.org/10.1016/j.foodchem.2017.11.073 Available at https://centaur.reading.ac.uk/74115/

It is advisable to refer to the publisher's version if you intend to cite from the work. See Guidance on citing.

Published version at: https://doi.org/10.1016/j.foodchem.2017.11.073

To link to this article DOI: http://dx.doi.org/10.1016/j.foodchem.2017.11.073

Publisher: Elsevier

All outputs in CentAUR are protected by Intellectual Property Rights law, including copyright law. Copyright and IPR is retained by the creators or other copyright holders. Terms and conditions for use of this material are defined in the End User Agreement. 


\section{CentAUR}

Central Archive at the University of Reading

Reading's research outputs online 
Authentication of Iceland Moss by UPLC-QToF-MS chemical profiling and DNA barcoding

Maonian $\mathrm{Xu}^{\mathrm{a}}$, Starri Heidmarsson ${ }^{\mathrm{b}}$, Margret Thorsteinsdottir ${ }^{\mathrm{a}}$, Marco

Kreuzer $^{\mathrm{c}}$, Julie Hawkinss ${ }^{\mathrm{c}}$, Sesselja Omarsdottir ${ }^{\mathrm{a}}$, Elin Soffia Olafsdottir ${ }^{\mathrm{a}, *}$

${ }^{a}$ Faculty of Pharmaceutical Sciences, University of Iceland, Hagi,

Hofsvallagata 53, IS-107 Reykjavik, Iceland (Emails: xum1 @ hi.is, margreth@hi.is, sesselo@hi.is, elinsol@hi.is)

${ }^{b}$ Icelandic Institute of Natural History, Akureyri Division, IS-600 Akureyri, Iceland (Email: starri@ni.is)

${ }^{c}$ School of Biological Sciences, University of Reading, Reading RG6 6BX, United Kingdom (Emails: marcokrz@gmail.com, j.a.hawkins@ @eading.ac.uk)

* Corresponding author

Elin Soffia Olafsdottir, Ph.D, Professor

Faculty of Pharmaceutical Sciences

University of Iceland

Hagi, Hofsvallagata 53,

IS-107 Reykjavik, Iceland

Tel: +354 5255804

Fax: +3545254071

Email: elinsol@hi.is 


\section{Abstract}

The lichen Cetraria islandica or Iceland Moss is commonly consumed as tea, food ingredients (e.g. in soup or bread) and herbal medicines. $C$. islandica, which has two chemotypes, can be difficult to distinguish from the sister species Cetraria ericetorum. They are collectively referred to as the Cetraria islandica species complex. This study aimed to use an UPLCQToF-MS chemical profiling together with DNA barcoding to distinguish species and chemotypes of the $C$. islandica species complex. Our results show that the two chemotypes of $C$. islandica are clearly distinguishable from each other and from $C$. ericetorum by the chemometric approach. The RPB2 barcode was able to differentiate $C$. islandica from $C$. ericetorum with a barcode gap, but the widely used nrITS barcode failed. Neither of them could discriminate chemotypes of $C$. islandica. In conclusion, this integrative approach involving chemical profiling and DNA barcoding could be applied for authentication of Iceland Moss materials.

Keywords: Cetraria islandica, Cetraria ericetorum, DNA barcoding, chemical profiling, authentication 
3 Taxonomically, Cetraria islandica or Iceland Moss is not a moss species

4 but a lichen taxon and the classification is based on the symbiotic fungal

5 partner (Parmeliaceae, ascomycete) (Ingolfsdóttir, 2000). This lichen is

6 consumed in Iceland as tea, food ingredients (e.g. in milk soups and bread)

7 and herbal medicines (Xu et al., 2016). Considerable morphological and

8 chemical variations have been found among Icelandic populations of $C$.

9 islandica and two chemotypes have been reported (Kristinsson, 1969). They

10 consist of the fumarprotocetraric acid (FA)-producing and FA-deficient

11 races, where the latter chemotype has exclusively been found in Iceland

12 (Kristinsson, 1969). Traditional use seems to favor the FA-deficient

13 chemotype of $C$. islandica, which is believed to be less bitter (Kristinsson,

14 1968). Furthermore, the species boundaries between $C$. islandica and its

15 sibling species Cetraria ericetorum are still ambiguous: C. ericetorum has

16 similar morphology to certain morphotypes of $C$. islandica and it is reported

17 to be FA-deficient. Together $C$. islandica and C. ericetorum are collectively

18 called the Cetraria islandica species complex (Kristinsson, 1969; Thell,

19 Stenroos, \& Myllys, 2000). Their chemical profiles, particularly of the $C$.

20 islandica FA-deficient chemotype and C. ericetorum, have not been

21 thoroughly investigated for food safety, and an accurate identification

22 method for these lichen materials is needed.

23

24 Chemical profiling or fingerprinting, in particular when using an untargeted

25 approach, can directly detect chemical hazards and contaminants in food or

26 herbal materials, with the limitation that their species sources cannot be

27 determined (de Boer, Ichim, \& Newmaster, 2015). Chemometric analysis

28 using complex metabolite datasets has shown great potential in the

29 inspection of food adulteration as well as in the characterization of markers

30 for adulteration detection (Cubero-Leon, Peñalver, \& Maquet, 2014). 
31 Untargeted chemical profiling is especially useful in the distinction of

32 closely-related plant species, where certain genetic markers may not be

33 informative (Messina, Callahan, Walsh, Hoebee, \& Green, 2014). That

34 approach has been successfully applied to the lichen Ramalina siliquosa

35 complex using liquid chromatography-mass spectrometry (LC-MS) (Parrot,

36 Jan, Baert, Guyot, \& Tomasi, 2013).

37

38 Recently, DNA barcoding has emerged as an effective tool in the

39 identification of plant and animal materials using defined species-specific

40 DNA markers. It has found wide application in the authentication and

41 traceability of food materials (Galimberti et al., 2013). This approach has

42 been extended to the authentication of multiple ingredients samples using a

43 more advanced DNA metabarcoding approach, which involves next

44 generation sequencing (Staats et al., 2016). Practically, DNA barcoding has

45 been applied for authentication of fungi-based dietary products (Raja, Baker,

46 Little, \& Oberlies, 2017). Furthermore, identification of lichenized fungi

47 using DNA barcoding has been successfully performed using the fungal

48 nuclear ribosomal internal transcribed spacer region (nrITS) (Kelly et al.,

49 2011), which has been proposed as the universal DNA barcode for fungi

50 (Schoch et al., 2012).

51

52 Two DNA barcodes, nrITS and RPB2 (the second largest subunit of

53 ribosomal polymerase II) were selected for this study on the $C$. islandica

54 lichen materials. Although the widely used nrITS region is known to

55 provide a sufficient amount of variation to distinguish between most fungal

56 species and is represented by many reference sequences in public databases,

57 some drawbacks for DNA barcoding and especially DNA metabarcoding

58 have been reported (Větrovský, Kolařík, Žifčáková, Zelenka, \& Baldrian,

59 2016). While nrITS can identify species, its multi-copy nature of the ITS

60 region may render problems with relative quantification of species in mixed 

RPB2 gene has been proposed as an alternative to the nrITS region, which could overcome some of these challenges (Větrovský et al., 2016). The performance of RPB2 will be compared to that of nrITS in our study.

The overall aim of this study was to explore the usefulness of an authentication approach for Cetraria islandica species complex using UPLC-QToF-MS chemical profiling and DNA barcoding. Specific objectives were: Firstly, to distinguish chemotypes of the species complex by comparing their UPLC-QToF-MS chemical profiles using chemometric data analysis, and secondly to compare the discriminatory power of RPB2 and nrITS barcodes for the taxa of the $C$. islandica species complex.

\section{Materials and Methods}

Cetraria islandica (L.) Ach. (English: Iceland Moss; Icelandic: fjallagrös) and Cetraria ericetorum Opiz specimens were collected in Iceland. Authentic specimens of $C$. islandica are provide by lichenologists from the Icelandic Institute of Natural History, Akureyri, Iceland (AMNH). Collected voucher specimens are deposited at the AMNH herbarium. Intraspecific morphological variation of Iceland Moss (C. islandica) as well as the interspecific similarity between the two species (C. islandica and $C$. ericetorum) can be seen in Figure 1. Additional C. ericetorum type specimens were kindly provided by Dr. Stefan Ekman, Museum of

89 Evolution, Uppsala University, Uppsala, Sweden. The chemotypes of $C$. islandica and C. ericetorum were tested using a conventional spot testing 
91 method (Kristinsson, 1969). Briefly, a small fragment was cut from a thallus

92 with a blade, and drops of $p$-phenylendiamine (PD) solution (ca. $2 \%$ in

93 ethanol) were added to lichen medulla on a white paper with a glass

94 capillary tube. Then the medullary color reactions were visualized under a

95 stereoscope. Specimens showing a red medullary color after spot testing

96 were assigned as PD+, while the ones without color change as PD-. PD spot

97 testing was carried out on fragments from three different parts of the thallus,

98 to make sure the chemotype. Fragments were discarded immediately after

99 testing. Voucher information and gene accession numbers are provided in

100 Online Resource (see Table S1). In total, 30 specimens of PD+ C. islandica,

10115 specimens of PD- $C$. islandica and 18 specimens of uniformly PD- $C$.

102 ericetorum were identified.

103

104

2.2 Chemical profiling

105

106

2.2.1 LC-MS analysis

107

108 Air-dried lichen thallus (ca. $20 \mathrm{mg}$ ) was weighed and ground into powders

109 under liquid nitrogen. Powdered lichen materials were macerated with

110 acetone under shaking in ambient temperature for $2 \mathrm{~h}$. The extraction was

111 repeated twice. Extracts were combined and evaporated with nitrogen gas

112 flow. Dried residues were then solubilized in HPLC-grade acetonitrile

113 (ACN), diluted into $0.1 \mathrm{mg} / \mathrm{mL}$ and filtered (pore size $0.45 \mu \mathrm{m}$; GE

114 healthcare, UK) before analyses by Waters ACUITY UPLC ${ }^{\mathrm{TM}}$ (Waters

115 Corporation, Milford, MA, USA) coupled to Waters Q-ToF SYNAPT G1

116 mass spectrometer (Waters MS Technologies, Manchester, UK).

117

118 The UPLC system was equipped with a binary solvent delivery system and

119 autosampler. Chromatographic separation of lichen compounds was

120 conducted on an ACQUITY UPLC BEH C18 column (2.1 mm x $100 \mathrm{~mm}$, 
$1211.7 \mu \mathrm{m}$; Waters corp., Milford, MA, USA). The column oven was kept at

$12240^{\circ} \mathrm{C}$ and the autosampler was maintained at $6.0^{\circ} \mathrm{C}$. The mobile phase

123 consisted of solvent $\mathrm{A}: \mathrm{H}_{2} \mathrm{O}$ with $0.1 \%$ formic acid in water and solvent $\mathrm{B}$ :

$1240.1 \%$ formic acid in ACN. Gradient elution was used at a flow rate of 0.40

$125 \mathrm{~mL} / \mathrm{min}$ as follows: $30 \% \mathrm{~B}, 0-1 \mathrm{~min}$; linear gradient from $30 \% \mathrm{~B} / 70 \% \mathrm{~A}$ to

$12670 \% \mathrm{~B} / 30 \% \mathrm{~A}, 1-3 \mathrm{~min}$; linear gradient from $70 \% \mathrm{~B} / 30 \%$ A to $100 \% \mathrm{~B}, 3-9$

$127 \mathrm{~min}$; holding at $100 \% \mathrm{~B}, 9-13 \mathrm{~min}$; linear gradient from $100 \% \mathrm{~B}$ to $30 \%$

128 B/70\% A, 13-14 min; holding at 30\% B/70\% A, 14-15 min. Pooled samples

129 were used as quality control. The injection volume was $5 \mu \mathrm{L}$.

130

131 The Synapt G1 QToF-MS mass spectrometer was operated in negative

132 electrospray ionization mode (capillary voltage $3.0 \mathrm{kV}$, source temperature

$133120^{\circ} \mathrm{C}$, desolvation temperature $400^{\circ} \mathrm{C}$, cone gas flow $50 \mathrm{~L} / \mathrm{h}$, desolvation

134 nitrogen gas flow $800 \mathrm{~L} / \mathrm{h}$ ). Ions with mass range 50 to $1600 \mathrm{~m} / \mathrm{z}$ (mass to

135 charge ratio) were scanned. All samples were analyzed in triplicates. Details

136 of UPLC-QToF-MS analysis are as previously described (Xu et al., 2017).

137 The UPLC-QToF-MS system and data acquisition were controlled by the

138 MassLynx v4.1 software (Waters Corp., Milford. USA).

139

140

2.2.2 Chemometric data analysis

141

142 MS spectra were aligned and normalized using MakerLynx v4.1. Collection

143 parameters were set as 50 counts, mass window $0.05 \mathrm{Da}$ and retention time

144 window $0.2 \mathrm{~min}$. Replicate percentage value was set at $50 \%$. Normalized

145 data were introduced into SIMCA v14.1 software (Sartorius Stedim Data

146 Analytics, Umeå, Sweden) for principal component analysis (PCA). PCA

147 could provide a holistic overview of the grouping of lichen specimens,

148 which was based on chemical data from organic extracts. Compounds were

149 identified by comparing their MS/MS spectra and fragmentation patterns 
150 with those from isolated pure compounds, previously published data and

151 public databases (Metlin and ChemSpider).

152

153

2.3 Molecular analysis

154

155

2.3.1 DNA extraction, PCR and sequencing

156

157 Air-dried lichen residues after acetone maceration were used for total DNA

158 extraction following the CTAB protocol (Cubero, Crespo, Fatehi, \& Bridge,

159 1999). Lichen DNA extracts were stored in TE buffer $(\mathrm{pH} 8.0)$ at $-20^{\circ} \mathrm{C}$

160 until use. Polymerase chain reactions (PCRs) were performed to amplify the

161 fungal nuclear ribosomal internal transcribed spacer (nr ITS) and the second

162 largest subunit of RNA polymerase II (RPB2). Each reaction $(25 \mu \mathrm{L})$

163 contained $1 \times$ standard Taq reaction buffer, $200 \mu \mathrm{M}$ dNTPs, $0.2 \mu \mathrm{M}$ forward

164 and reverse primer, 1.25 units of Taq DNA polymerase (New England

165 Biolabs), $1 \mu \mathrm{L}$ DNA template, and PCR-grade water. The fungi-specific

166 primers used for the amplification of nr ITS region were: ITS1F (5'-

167 CTTGGTCATTTAGAGGAAGTAA-3') (Gardes \& Bruns, 1993) and ITS4

168 (5'-TCC CCGCTTATTGATATGC-3') (White, Bruns, Lee, \& Taylor,

169 1990), while the primers for the RPB2 regions were: RPB2-6F (5'-

170 TGGGGKWTGGTYTGYCCTGC-3') (Liu, Whelen, \& Hall, 1999) and

171 fRPB2-7cR (5'-CCCATRGCTTGYTTRCCCAT-3') (Liu et al., 1999). PCR

172 amplification was carried out in a Perkin-Elmer Gene Amp PCR system

1739700 thermal cycler. The PCR cycling conditions for nrITS were: initial

174 denaturation at $94^{\circ} \mathrm{C}$ for $3 \mathrm{~min}, 34$ cycles of $94^{\circ} \mathrm{C}$ for $40 \mathrm{~s}, 54^{\circ} \mathrm{C}$ for $40 \mathrm{~s}$,

$17568^{\circ} \mathrm{C}$ for $1 \mathrm{~min}$, then final extension at $68^{\circ} \mathrm{C}$ for 5 min before cooling down

176 to $4^{\circ} \mathrm{C}$. A touchdown PCR program was used for RPB2 region: $94^{\circ} \mathrm{C}$ for 4

177 min, followed by 6 cycles of $94^{\circ} \mathrm{C}$ for $1 \mathrm{~min}, 55-50^{\circ} \mathrm{C}\left(\right.$ decrease $1^{\circ} \mathrm{C}$ per

178 cycle) for $1 \mathrm{~min}$ and $68^{\circ} \mathrm{C}$ for $1 \mathrm{~min}$, then 32 cycles of $94^{\circ} \mathrm{C}$ for $1 \mathrm{~min}, 50^{\circ} \mathrm{C}$

179 for $1 \mathrm{~min}$ and $68^{\circ} \mathrm{C}$ for $1 \mathrm{~min}$, and final extension at $68^{\circ} \mathrm{C}$ for $7 \mathrm{~min}$, before 
181 picture refers to Online Resource Figure S1), purified using ExoSAP

182 (Fermentas) and sent for Sanger sequencing by Marogen Inc. using the same

183 set of primers as used in PCRs.

184

\subsubsection{DNA barcoding analysis}

186

187 The discriminatory power of the nrITS and RPB2 barcodes was assessed

188 according to the monophyly criterion and the DNA barcoding gap concept

189 (Meyer \& Paulay, 2005). The sequences representing each barcode were

190 aligned using MAFFT v7.215 (Katoh \& Standley, 2013) with default

191 parameters and trimmed if necessary. Phylogenetic trees using the Genbank

192 sequences of $C$. sepincola (accession number KC990137.1 for nrITS) as

193 outgroups were built with RAxML v. 8.0.26 (Stamatakis, 2014) with 100

194 rapid bootstrap replicates under the GTRGAMMA model. The DNA

195 barcode gap analysis was conducted on $C$. islandica and its sister species $C$.

196 ericetorum using the R package SPIDER (Brown et al., 2012), using the

197 best-fitting substituion models to measure pair-wise distances. Best-fitting

198 substitution models for each region (TIM2+G for nrITS; TIM2+I for RPB2)

199 were chosen by using the Aikaike Information Criterion (AIC) in

200 jModelTest 2 (Darriba, Taboada, Doallo, \& Posada, 2012). Because the

201 TIM2+G and TIM2+I models were not available in the $\mathrm{R}$ package APE

202 (Paradis, Claude, \& Strimmer, 2004), which was used to calculate pairwise

203 distances, the next best-fitting model for both alignments, $\operatorname{TrN}+\mathrm{G}$, was used.

204

205 The number of false positive and false negative identifications along a DNA

206 divergence threshold were calculated and plotted using the R package

207 SPIDER (Brown et al., 2012). Additionally, the minimum interspecific and

208 maximum intraspecific divergence for each sequence was calculated and 209 plotted. 
215 Chemical profiling of $C$. islandica organic extracts has been carried out

216 before using high performance liquid chromatography-ultraviolet detection

217 (HPLC-UV) (Fernández-Moriano, Divakar, Crespo, \& Gómez-Serranillos,

218 2015; Gudjónsdóttir \& Ingólfsdóttir, 1997). Those previously used methods

219 lack separation efficiency and sensitivity, and thus may underestimate the

220 chemical diversity of $C$. islandica, e.g. (+)-roccellaric acid 6 was found in $C$.

221 islandica using a fluorous tag-catch and release approach (Horhant, Lamer,

222 Boustie, Uriac, \& Gouault, 2007), but was previously overlooked due to

223 poor chromatographic separation. Additionally, HPLC-UV (Fernández-

224 Moriano et al., 2015) analysis using high UV wavelengths may overlook the

225 content of those aliphatic lichen acids (i.e. compounds 5-8), which are poor

226 UV absorbants. The current UPLC method achieved the separation of

227 compound $\mathbf{6}$ from its analogues $\mathbf{7}$ and $\mathbf{8}$. A list of detected compounds is

228 provided in Table S2, and the structures of major lichen secondary

229 metabolites from the C. islandica species complex are illustrated in Figure 2.

231 Compounds 1-8 were identified in our study by comparing their molecular

232 masses, fragmentation pathway and chromatographic properties with

233 reference data as well as authentic standards isolated in previous studies

234 (Bessadóttir et al., 2014; Gudjónsdóttir \& Ingólfsdóttir, 1997). MS² spectra

235 of each compound and their fragmentation patterns are provided in Online

236 Resource (see Figures S2-S4). MS chromatograms (Figure 3) show that (+)-

237 protolichesterinic acid $\mathbf{7}$ and its derivatives (i.e. $\mathbf{6}$ and $\mathbf{8}$ ) are the dominant

238 compounds in organic extracts detected in negative ion mode, followed by

239 minor components, such as protocetraric acid $\mathbf{1}$ and fumarprotocetraric acid 
240 3. The stereochemical diversity of (+)-protolichesterinic acid 7 seems to be

241 largely underestimated before, since two compounds (i.e. 7A and 7B) were

242 detected with the same molecular formula, molecular ions and

243 fragmentation patterns (Figure S4) with compound 7 (Table S2 and Figure

244 3). In C. ericetorum, an additional unknown compound $6 \mathbf{A}$ in the peak

245 eluting out at $5.77 \mathrm{~min}$ (Figure 3c) was detected having the same mass to

246 charge ratio as well as fragmentation pattern as (+)-roccellaric acid $\mathbf{6}$, which

247 suggests that $\mathbf{6 A}$ could be a stereoisomer of compound $\mathbf{6}$ (Figure S4). Up to

248 now, only one stereochemical form of roccellaric acid has been reported in

249 nature, namely (+)-roccellaric acid 6 in C.islandica (Horhant et al., 2007).

250 Three additional stereochemical forms have been synthesized by Mulzer et

251 al. (Mulzer, Salimi, \& Hartl, 1993). Minor compounds 1 and $\mathbf{3}$ eluted quite

252 early $\left(t_{R}=2.49\right.$ and $2.96 \mathrm{~min}$, respectively) under the chromatographic

253 conditions used, reflecting that they are more water-soluble than compounds

254 5-8. Fumarprotocetraric acid $\mathbf{3}(50 \mathrm{mg})$ is reported to be moderately soluble

255 in $30 \mathrm{~mL}$ phosphate buffer at $\mathrm{pH} 7.4$ (Syers, 1969), while the solubility of

256 compound 3 is low $(1 \mathrm{mg} / \mathrm{L})$ in $90 \%$ acetonitrile with $1 \%$ phosphoric acid

257 (Gudjónsdóttir \& Ingólfsdóttir, 1997). Thus, polarity and pH of the

258 extraction solvent can be expected to have considerable influence on the

259 extraction efficiency of these lichen acids (i.e. compounds 1-4).

260

261 As a conventional diagnostic tool, the PD spot test was used to check the

262 chemotype and the presence of compound 3 in C. islandica (Kristinsson,

263 1969). From LC-MS chromatograms shown in Figure 3, the red color

264 reaction by PD spot testing was found to correlate with the presence of

265 compouds $\mathbf{1}$ and $\mathbf{3}$, while these compounds were absent in the PD- $C$.

266 islandica chemotype and C. ericetorum. The presence of the aliphatic lichen

267 acids (i.e. compounds 5-8) did not result in a red color reaction. The co-

268 occurence of compouds $\mathbf{1}$ and $\mathbf{3}$ in organic extracts of $C$. islandica has been

269 found in literature (Fernández-Moriano et al., 2015). 
271 The two-component PCA score plot (Figure 4) of the UPLC-QToF-MS data

272 provides the visualization of how different chemical groups relate to each

273 other. Three chemical groups were formed based on their chemical profiles,

274 representing the PD- (CI PD-) and PD+ chemotypes (CI PD+) of $C$.

275 islandica and C. ericetorum (CE). The first component explains $43.6 \%$

276 chemical variations, mainly interspecific differences between CE and CI.

277 The secondary component accounts for $10.4 \%$ variations, mainly

278 intraspecific differences between CI PD+ and CI PD-. PCA is a useful tool

279 in summarizing metabolite data and revealing groupings of food ingredients

280 from different biological origins (Azilawati, Hashim, Jamilah, \& Amin,

281 2015; Cubero-Leon et al., 2014). From the Figure 4, the lichen $C$. islandica

282 shows high intraspecific chemical variations in Iceland with two

283 chemotypes recognized as reported before (Kristinsson, 1969), while

284 Icelandic C. ericetorum shows relatively less variation, even when

285 compared with non-Icelandic $C$. ericetorum specimens. This could partly be

286 explained by the limited distribution of $\mathrm{CE}$, resulting in less variation. $\mathrm{CE}$

287 has a restricted geographic distribution in north and east Iceland, whereas CI

288 has a rather wide distribution around Iceland (Thell \& Moberg, 2011).

289

290

3.2 DNA barcoding

291

292 Sizes of PCR products were ca. $\sim 600-900 \mathrm{bp}$ for fungal nrITS and ca. $\sim 900$

293 bp for fungal RPB2 (Online Resource Figure S1). The variation of the

294 fungal nrITS PCR products was due to the presence of a group I intron

295 sequence in the longer amplicons, and absence in the short ones. In total 97

296 new sequence were obtained, including 48 for RPB2 and 49 for fungal

297 nrITS. PCRs of a few old herbarium reference specimens were not

298 successful (Online Resource Table S1). 
300 The phylogenetic tree based on the ITS region (Figure 5a) shows that $C$.

301 ericetorum is paraphyletic and nested within the $C$. islandica clade, whereas

302 both $C$. ericetorum and $C$. islandica are monophyletic in the RPB2 tree

303 (Figure 5b). Therefore the phylogenetic analyses support RPB2 as a barcode

304 with power to discriminate between the two species of Cetraria, but shows

305 that the nrITS barcode does not discriminate the species under study. The

306 pairwise distance analysis supports this interpretation, revealing that RPB2

307 is able to distinguish the two taxa, whereas the nrITS region always yields

308 false positive or negative identifications (Figure 6). There are other cases

309 where the nrITS region fails to discriminate lichenized fungi (Kelly et al.,

310 2011; Pino-Bodas, Martín, Burgaz, \& Lumbsch, 2013), though the nrITS

311 region revealed interspecific barcoding gaps among most species of genera

312 Melanelia and Montanelia ( Leavitt et al., 2014; Pino-Bodas et al., 2013).

313 The failure of the nrITS region in this case might be attributed to

314 intragenomic polymorphism in the ITS region, a phenomenon described in

315 other lichen-forming fungi (Kelly et al., 2011; Mark et al., 2016). It has also

316 been reported that the nrITS region alone is not suitable to estimate the

317 phylogenetic relationships within the $C$. islandica group (Thell et al., 2000).

319 The limited application of RPB2 as a barcoding region has been explained

320 by difficult PCR amplification and sequencing (Schoch et al., 2012).

321 Specimens stored for over 3 years have shown problems in PCR

322 amplification (Kelly et al., 2011). We have, however, not encountered a

323 PCR amplification problem for either locus even with specimens which are

32415 years old. Successful PCR amplification of the RPB2 region using even

325 older specimens (Cladonia sp.) of about 30 years has also been recorded

326 (Pino-Bodas et al., 2013). Age-dependent problems with PCR amplification

327 may be taxon-specific, as well as influenced by the DNA extraction method

328 in use. We noted that the sequence alignment of RPB2 is much simpler. In

329 contrast to the hypervariability of the nrITS region, RPB2 is also 
331 et al., 2016). We therefore reject the nrITS region and propose the RPB2

332 region as an efficient DNA barcode for testing medicinal products

333 containing Iceland Moss, at least in terms of discriminating between $C$.

334 ericetorum and C. islandica.

336 Although the RPB2 region is effective for discriminating between species,

337 chemotypes of $C$. islandica are not discriminated (Figure 5). In Figure 5b, $C$.

338 islandica specimens from Iceland show two strongly supported clades, I and

339 II. All of the $C$. islandica PD- chemotype specimens fall into clade I, but are 340 interspersed with PD+ chemotypes, while clade II contains exclusively PD+

341 C. islandica specimens. Some lichen chemotypes have been shown to be

342 monophyletic (Fehrer, Slavíková-Bayerová, \& Orange, 2008), but they can

343 also be not (Lutsak, Fernández-Mendoza, Nadyeina, Şenkardeşler, \&

344 Printzen, 2017).

346 Domestically, Cetraria islandica is sold as whole lichen-thalli food

347 ingredients or tea in Iceland. Accurate identification is generally not

348 difficult for taxonomic experts, but it may prove intractable to identify

349 powdered lichen materials, which lack morphological or sometimes

350 chemical characters. DNA barcoding as outlined here could substantially

351 facilitate identification by comparing new sequence data with reference data

352 generated from expertly identified voucher specimens.

354 The current study focused on the authentication of natural lichen materials

355 without downstream processing. In case of highly processed herbal

356 materials where DNA may undergo considerable degradation, an alternative

357 method could be double gene targeting PCR, which amplifies selected

358 shorter regions (e.g. 70-150 bp) (Hossain et al., 2016, 2017). 

Iceland Moss

363 Lichen material authentication generally operates at the species level and as

364 shown in this study DNA barcoding using RPB2, is an efficient method for

365 species identification in the $C$. islandica species complex. The advantage of

366 DNA barcoding is in identification of raw plant materials, sources of

367 contaminants and species composition (de Boer et al., 2015), which is

368 beyond the scope of chemical analysis. Generally, chemical profiling of

369 lichen secondary metabolites do not have the independent role in

370 identification/authentication of lichen species (Lumbsch, 1998). First, the

371 utility of metabolite data in lichen identification varies among lichen

372 taxa/populations. Our results (Table S2 and Figure 4) have demonstrated the

373 utility of chemical profiling in discriminating species $(C$. islandica and $C$.

374 ericetorum) and chemotypes (PD+ and PD-) in the Cetraria islandica

375 species complex. However, chemical profiling may have limited utility in

376 species discrimination where remarkable chemical variations (e.g. different

377 in major lichen compounds) are present, such as the lichen Ramalina

378 siliquosa (Lumbsch, 1998; Parrot et al., 2013). Such a huge variation may

379 pose a challenge in lichen identification: how much chemical variation is

380 allowed to define a species? To address this problem, it has been suggested

381 that chemical characters be correlated with other characters, preferentially

382 genetic sequence data (Lumbsch, 1998). The correlation between

383 phylogenetic relationship and chemotyping (i.e. PD+ and PD-) was

384 investigated in our study (Figure 5b).

386 Although chemical profiling does not have an independent role in lichen

387 species identification/Iceland Moss authentication, it is indispensable for the

388 quality control of marker or health-beneficial components. It can provide

389 both qualitative and quantitative information on phytochemical composition 
392 chemical variants, which is superior to DNA barcoding.

394 In conclusion, this study highlights the integrative use of chemical profiling

395 and DNA barcoding for the authentication of Iceland Moss. The members of

396 Cetraria islandica species complex were easily characterized using

397 chemometric tools. Furthermore, DNA barcodes were compared and the

398 locus RPB2 proved to be superior to nrITS in distinguishing species of $C$.

399 islandica species complex. Our study shows how chemical profiling and

400 DNA barcoding can be used to differentiate chemical variants and species in

401 the complex, and suggests the use of this integrated approach for accurate

402 characterization of this closely related taxa as well as other plant materials

403 used for human consumption.

404

405 Acknowledgements

406

407 This work was supported by the People Programme (Marie Curie Actions)

408 of the European Union's Seventh Framework Programme FP7/2007-2013/

409 [grant number 606895]; Bergthora and Thorsteinn Scheving Thorsteinsson

410 Fund. Professor Kristinn P. Magnusson and Ph.D student Maney

411 Sveinsdottir, University of Akureyri, Iceland, are acknowledged for their

412 help in molecular analysis. The authors are particularly grateful to Dr.

413 Hörður Kristinsson (AMNH) for specimen collection and thoughtful

414 discussion.

415

416 Conflicts of interest: none

417

$418 \quad$ References 

method using 6-aminoquinolyl-N-hydroxysuccinimidyl carbamate incorporated with normalization technique in principal component analysis to differentiate the bovine, porcine and fish gelatins. Food Chemistry, 172, 368-376.

Bessadóttir, M., Skúladóttir, E., Gowan, S., Eccles, S., Ómarsdóttir, S., \& Ögmundsdóttir, H. M. (2014). Effects of anti-proliferative lichen metabolite, protolichesterinic acid on fatty acid synthase, cell signalling and drug response in breast cancer cells. Phytomedicine, 2l(12), 1717-1724. https://doi.org/10.1016/j.phymed.2014.08.006

Brown, S. D. J., Collins, R. A., Boyer, S., Lefort, M. C., Malumbres-Olarte, J., Vink, C. J., \& Cruickshank, R. H. (2012). Spider: An R package for the analysis of species identity and evolution, with particular reference to DNA barcoding. Molecular Ecology Resources, 12(3), 562-565. https://doi.org/10.1111/j.1755-0998.2011.03108.x

Cubero-Leon, E., Peñalver, R., \& Maquet, A. (2014). Review on metabolomics for food authentication. Food Research International, 60, 95-107. https://doi.org/10.1016/j.foodres.2013.11.041

Cubero, O. F., Crespo, A., Fatehi, J., \& Bridge, P. D. (1999). DNA extraction and PCR amplification method suitable for fresh, herbarium-stored, lichenized, and other fungi. Plant Systematics and Evolution, 216(3-4), 243-249. https://doi.org/10.1007/BF01084401

Darriba, D., Taboada, G. L., Doallo, R., \& Posada, D. (2012). jModelTest 2: more models, new heuristics and parallel computing. Nature Methods, 9(8), 772-772. https://doi.org/10.1038/nmeth.2109

de Boer, H. J., Ichim, M. C., \& Newmaster, S. G. (2015). DNA Barcoding and Pharmacovigilance of Herbal Medicines. Drug Safety, 38(7), 611620. https://doi.org/10.1007/s40264-015-0306-8

Fehrer, J., Slavíková-Bayerová, Š., \& Orange, A. (2008). Large genetic divergence of new, morphologically similar species of sterile lichens from Europe (Lepraria, Stereocaulaceae, Ascomycota): Concordance of DNA sequence data with secondary metabolites. Cladistics, 24(4), 443-458. https://doi.org/10.1111/j.1096-0031.2008.00216.x

Fernández-Moriano, C., Divakar, P. K., Crespo, A., \& Gómez-Serranillos, M. P. (2015). Neuroprotective activity and cytotoxic potential of two Parmeliaceae lichens: Identification of active compounds.

Phytomedicine, 22(9), 847-855. https://doi.org/10.1016/j.phymed.2015.06.005

Galimberti, A., De Mattia, F., Losa, A., Bruni, I., Federici, S., Casiraghi, M., Martellos, S., Labra, M. (2013). DNA barcoding as a new tool for food traceability. Food Research International, 50(1), 55-63. https://doi.org/10.1016/j.foodres.2012.09.036

Gardes, M., \& Bruns, T. D. (1993). ITS primers with enhanced specificity for basidiomycetes, application to the identification of mycorrihiza and rusts. Molecular Ecology, 2(May 2016), 113-118. https://doi.org/Doi 10.1111/J.1365-294x.1993.Tb00005.X

Gudjónsdóttir, G., \& Ingólfsdóttir, K. (1997). Quantitative determination of protolichesterinic- and fumarprotocetraric acids in Cetraria islandica by high-performance liquid chromatography. Journal of Chromatography A, 757(1-2), 303-306. https://doi.org/10.1016/S0021-9673(96)00670-X

Horhant, D., Lamer, a. C. L., Boustie, J., Uriac, P., \& Gouault, N. (2007). Separation of a mixture of paraconic acids from Cetraria islandica (L.) Ach. employing a fluorous tag-catch and release strategy. Tetrahedron Letters, 48(34), 6031-6033. https://doi.org/10.1016/j.tetlet.2007.06.077

Hossain, M. A. M., Ali, M. E., Abd Hamid, S. B., Asing, Mustafa, S., Mohd Desa, M. N., \& Zaidul, I. S. M. (2016). Double Gene Targeting Multiplex Polymerase Chain Reaction-Restriction Fragment Length Polymorphism Assay Discriminates Beef, Buffalo, and Pork 
Hossain, M. A. M., Ali, M. E., Hamid, S. B. A., Asing, Mustafa, S., Desa, M. N. M., \& Zaidul, I. S. M. (2017). Targeting double genes in multiplex PCR for discriminating bovine, buffalo and porcine materials in food chain. Food Control, 73, 175-184. https://doi.org/https://doi.org/10.1016/j.foodcont.2016.08.008

Ingolfsdóttir, K. (2000). Bioactive compounds from Iceland Moss. In B. S. Paulsen (Ed.), Bioactive Carbohydrate Polymers (pp. 25-36). Springer Netherlands. https://doi.org/10.1007/978-94-015-9572-8_3

Katoh, K., \& Standley, D. M. (2013). MAFFT multiple sequence alignment software version 7: Improvements in performance and usability. Molecular Biology and Evolution, 30(4), 772-780. https://doi.org/10.1093/molbev/mst010

Kelly, L. J., Hollingsworth, P. M., Coppins, B. J., Ellis, C. J., Harrold, P., Tosh, J., \& Yahr, R. (2011). DNA barcoding of lichenized fungi demonstrates high identification success in a floristic context. New Phytologist, 191(1), 288-300. https://doi.org/10.1111/j.14698137.2011.03677.x

Kristinsson, H. (1969). Chemical and Morphological Variation in the Cetraria islandica Complex in Iceland. The Bryologist. https://doi.org/10.1639/0007-2745(1969)72[344:CAMVIT]2.0.CO;2

Leavitt, S. D., Esslinger, T. L., Hansen, E. S., Divakar, P. K., Crespo, A., Loomis, B. F., \& Lumbsch, H. T. (2014). DNA barcoding of brown Parmeliae (Parmeliaceae) species: A molecular approach for accurate specimen identification, emphasizing species in Greenland. Organisms Diversity and Evolution, 14(1), 11-20. https://doi.org/10.1007/s13127-013-0147-1

Liu, Y. J., Whelen, S., \& Hall, B. D. (1999). Phylogenetic relationships among ascomycetes: evidence from an RNA polymerse II subunit. Molecular Biology and Evolution, 16(12), 1799-1808. https://doi.org/10.1086/523946

Lumbsch, H. T. (1998). The use of metabolic data in lichenology at the species and subspecies levels. Lichenologist, 30(4-5), 357-367.

Lutsak, T., Fernández-Mendoza, F., Nadyeina, O., Şenkardeşler, A., \& Printzen, C. (2017). Testing the correlation between norstictic acid content and species evolution in the Cetraria aculeata group in Europe. The Lichenologist, 49(1), 39-56. https://doi.org/10.1017/S0024282916000566

Mark, K., Cornejo, C., Keller, C., \& Flück, D. (2016). Barcoding lichenforming fungi using 454 pyrosequencing is challenged by artifactual and biological sequence variation. Genome, 704(May), 1-56. https://doi.org/10.1139/gen-2015-0189

Messina, A., Callahan, D. L., Walsh, N. G., Hoebee, S. E., \& Green, P. T. (2014). Testing the boundaries of closely related daisy taxa using metabolomic profiling. Taxon, 63(2), 367-376. https://doi.org/10.12705/632.15

Meyer, C. P., \& Paulay, G. (2005). DNA barcoding: Error rates based on comprehensive sampling. PLoS Biology, 3(12), 1-10. https://doi.org/10.1371/journal.pbio.0030422

Mulzer, J., Salimi, N., \& Hartl, H. (1993). First asymmetric synthesis of (+)and (-)-Roccellaric acid and dihydroprotolichesterinic acid. Tetrahedron: Asymmetry, 4(3), 457-471. https://doi.org/10.1016/S0957-4166(00)86089-9

Paradis, E., Claude, J., \& Strimmer, K. (2004). APE: Analyses of phylogenetics and evolution in R language. Bioinformatics, 20(2), 289-290. https://doi.org/10.1093/bioinformatics/btg412

Parrot, D., Jan, S., Baert, N., Guyot, S., \& Tomasi, S. (2013). Comparative metabolite profiling and chemical study of Ramalina siliquosa 
complex using LC-ESI-MS/MS approach. Phytochemistry, 89, 114124. https://doi.org/10.1016/j.phytochem.2013.02.002

Pino-Bodas, R., Martín, M. P., Burgaz, A. R., \& Lumbsch, H. T. (2013). Species delimitation in Cladonia (Ascomycota): A challenge to the DNA barcoding philosophy. Molecular Ecology Resources, 13(6), 1058-1068. https://doi.org/10.1111/1755-0998.12086

Raja, H. A., Baker, T. R., Little, J. G., \& Oberlies, N. H. (2017). DNA barcoding for identification of consumer-relevant mushrooms: A partial solution for product certification? Food Chemistry, 214, 383392. https://doi.org/10.1016/j.foodchem.2016.07.052

Schoch, C. L., Seifert, K. a., Huhndorf, S., Robert, V., Spouge, J. L., Levesque, C. A., Chen, W., Fungal Barcoding Consortium. (2012). Nuclear ribosomal internal transcribed spacer (ITS) region as a universal DNA barcode marker for Fungi. Proceedings of the National Academy of Sciences of the United States of America, 109(16), 1-6. https://doi.org/10.1073/pnas.1117018109

Staats, M., Arulandhu, A. J., Gravendeel, B., Holst-Jensen, A., Scholtens, I., Peelen, T., Prins, T.W., Kok, E. (2016). Advances in DNA metabarcoding for food and wildlife forensic species identification. Analytical and Bioanalytical Chemistry, 4615-4630. https://doi.org/10.1007/s00216-016-9595-8

Stamatakis, A. (2014). RAxML version 8: A tool for phylogenetic analysis and post-analysis of large phylogenies. Bioinformatics, 30(9), 13121313. https://doi.org/10.1093/bioinformatics/btu033

Syers, J. K. (1969). Chelating ability of fumarprotocetraric acid and Parmelia conspersa. Plant and Soil, 31(1), 205-208. https://doi.org/10.1007/BF01373043

Thell, A., \& Moberg, R. (2011). Nordic Lichen Flora. Volume 4. Parmeliaceae. Museum of Evolution, Uppsala University.

Thell, A., Stenroos, S., \& Myllys, L. (2000). A DNA study of the Cetraria aculeata and C. islandica groups. Folia Cryptog. Estonica. Fasc., 36, 95-106.

Větrovský, T., Kolařík, M., Žifčáková, L., Zelenka, T., \& Baldrian, P. (2016). The rpb2 gene represents a viable alternative molecular marker for the analysis of environmental fungal communities. Molecular Ecology Resources, 16(2), 388-401. https://doi.org/10.1111/1755-0998.12456

White, T. J., Bruns, T., Lee, S., \& Taylor, J. W. (1990). Amplification and direct sequencing of fungal ribosomal RNA genes for phylogenetics. In M. A. Innis, D. H. Gelfand, J. J. Sninsky, \& T. J. White (Eds.), PCR Protocols: a Guide to Methods and Applications (pp. 315-322). San Diego, USA: Academic Press INC.

Xu, M., Heidmarsson, S., Olafsdottir, E. S., Buonfiglio, R., Kogej, T., \& Omarsdottir, S. (2016). Secondary metabolites from cetrarioid lichens: chemotaxonomy, biological activities and pharmaceutical potential. Phytomedicine, 23(5), 441-459. https://doi.org/10.1016/j.phymed.2016.02.012

Xu, M., Heidmarsson, S., Thorsteinsdottir, M., Eiriksson, F. F., Omarsdottir, S., \& Olafsdottir, E. S. (2017). DNA barcoding and LC-MS metabolite profiling of the lichen-forming genus Melanelia : Specimen identification and discrimination focusing on Icelandic taxa. PLoS ONE, 12(5), e0178012. https://doi.org/10.1371/journal. pone.0178012 
595 Figure 1. Morphological variation and similarity of Iceland

596 Moss (Cetraria islandica) chemotypes and its sibling species

597 Cetraria ericetorum. C. islandica shows considerable

598 morphological variation, from wide (a and $\mathbf{c}$ ) to narrow thallus

599 (b and d). Two chemotypes were identified in C. islandica

600 specimens using $p$-phenylendiamine (PD) spot testing/staining,

601 including PD+ (red medullary color after staining; $\mathbf{a}$ and $\mathbf{b}$ ) and

602 PD- (no red medullary color after staining; $\mathbf{c}$ and $\mathbf{d}$ ). The lichen

603 C. ericetorum (e) is uniformly PD- and has narrow thallus.

604 Scale: $1 \mathrm{~cm}$.

605

606 Figure 2. Chemical structures of major lichen secondary

607 metabolites detected in the Cetraria islandica species complex.

608 Compounds include protocetraric acid $\mathbf{1}$, succinprotocetraric

609 acid $\mathbf{2}$, fumarprotocetraric acid $\mathbf{3}$, virensic acid $\mathbf{4}$,

610 nephrosterinic acid $\mathbf{5},(+)$-roccellaric acid $\mathbf{6},(+)-$

611 protolichesterinic acid $\mathbf{7}$ and (+)-lichesterinic acid 8. Minor

612 compounds refer to Table S2.

615 Figure 3. MS chromatograms of the PD+ (a) and PD- (b)

616 chemotypes of Cetraria islandica and PD- C. ericetorum (c)

617 and thallus color reaction by PD staining of PD+ (d) and PD- (e)

618 chemotypes of Cetraria islandica and PD- C. ericetorum (f). 
619 Major secondary metabolites are labelled corresponding to

620 structures 1-8 in Figure 2. Compounds 7A and 7B were

621 tentatively identified as stereoisomers of (+)-protolichesterinic

622 acid 7, and 6A a stereoisomer of (+)-roccellaric acid 6. Scale $=$

$6230.5 \mathrm{~mm}$.

624

625 Figure 4. PCA plot giving an overview of metabolite data and

626 indicative grouping of species and chemotypes in the Cetraria

627 islandica species complex. Three chemical groups include PD-

628 chemotype (CI PD-), C. islandica PD+ chemotype (CI PD+)

629 and C. ericetorum (CE). Authentic herbarium specimens were

630 marked as dark green (CI PD+), dark red (CI PD-) and grey

631 (CE).

632

633 Figure 5. Maximum likelihood (ML) trees of the Cetraria

634 islandica species complex reconstructed using barcode markers.

635 (a) ML tree reconstructed using the nrITS barcode, with $C$.

636 ericetorum specimens marked in red; (b) ML tree using the

637 RPB2 marker, where tree well-supported clades were identified:

638 I, II and III. The PD+ chemotype is labelled with a red dot after

639 each specimen. Bootstrap values $>70$ are shown above

640 branches in both trees.

641

642 Figure 6. Barcoding gap analysis of Cetraria islandica species

643 complex for each marker. (a) Number of false positive and 
644 false negative identifications along a threshold from $0.1 \%-4 \%$

645 DNA divergence; (b) Evaluation of inter- vs. intraspecific

646 divergence. The distances for each gene were calculated

647 according to the best model of evolution. Samples that are in

648 the top-left half of the plot have a greater minimum

649 interspecific than maximum intraspecific divergence and

650 exhibit a barcode gap. 


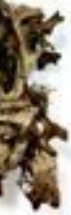

b
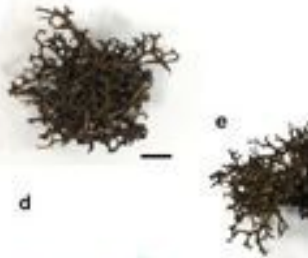

d
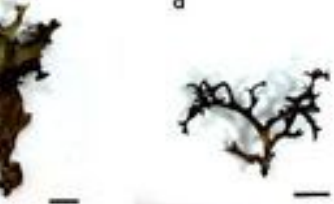
R
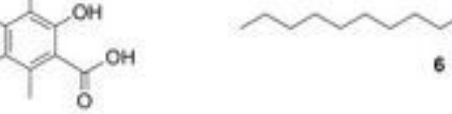

1

$\mathrm{H}_{5} \mathrm{O}_{4} 2$

$\mathrm{H}_{3} \mathrm{O}_{4} 3$
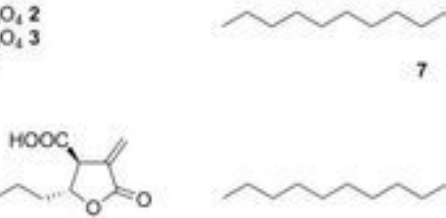


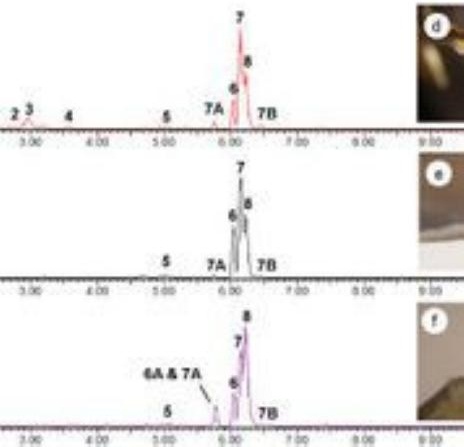


e

둥

a

s $\mathrm{n}$

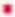 \\ an

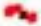 \\ CI PD.}

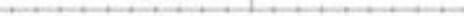

10

$\rightarrow$

$-6$

4

$-2$

0

2

4

6

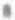




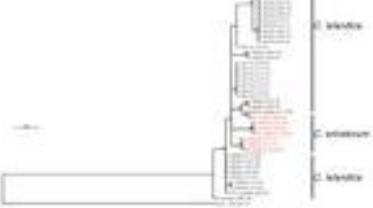

b

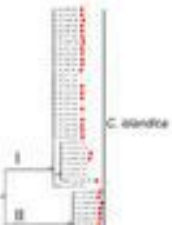


in =

is

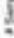

$14=$

14

$x=1$

1 120

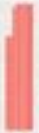

1

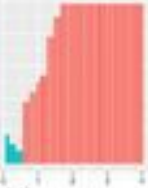

SThonteis
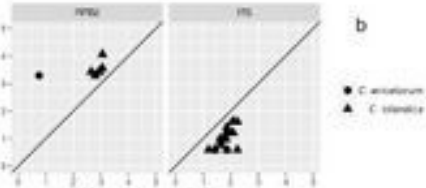

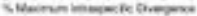




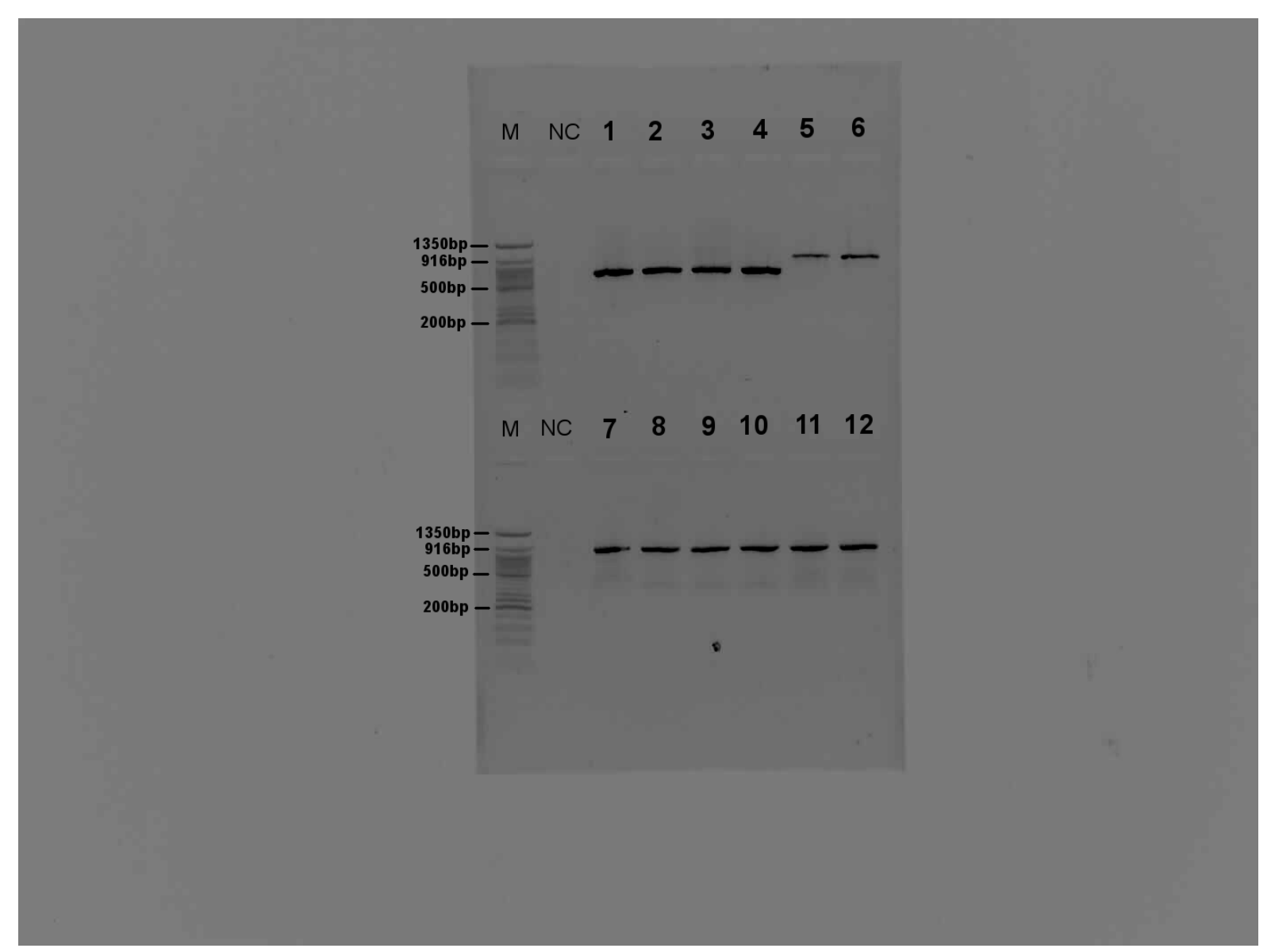

Figure S1. Agarose gel electrophoresis of PCR products from fungal nrITS and RPB2 loci. Lane 1-6: PCR products of fungal nrITS locus, ranging from 600 (intron-absent) to $900 \mathrm{bp}$ (intron-present). Lane 7-12: PCR products of fungal RPB2 locus of ca. 900 bp. M: ladder. NC: negative control. 

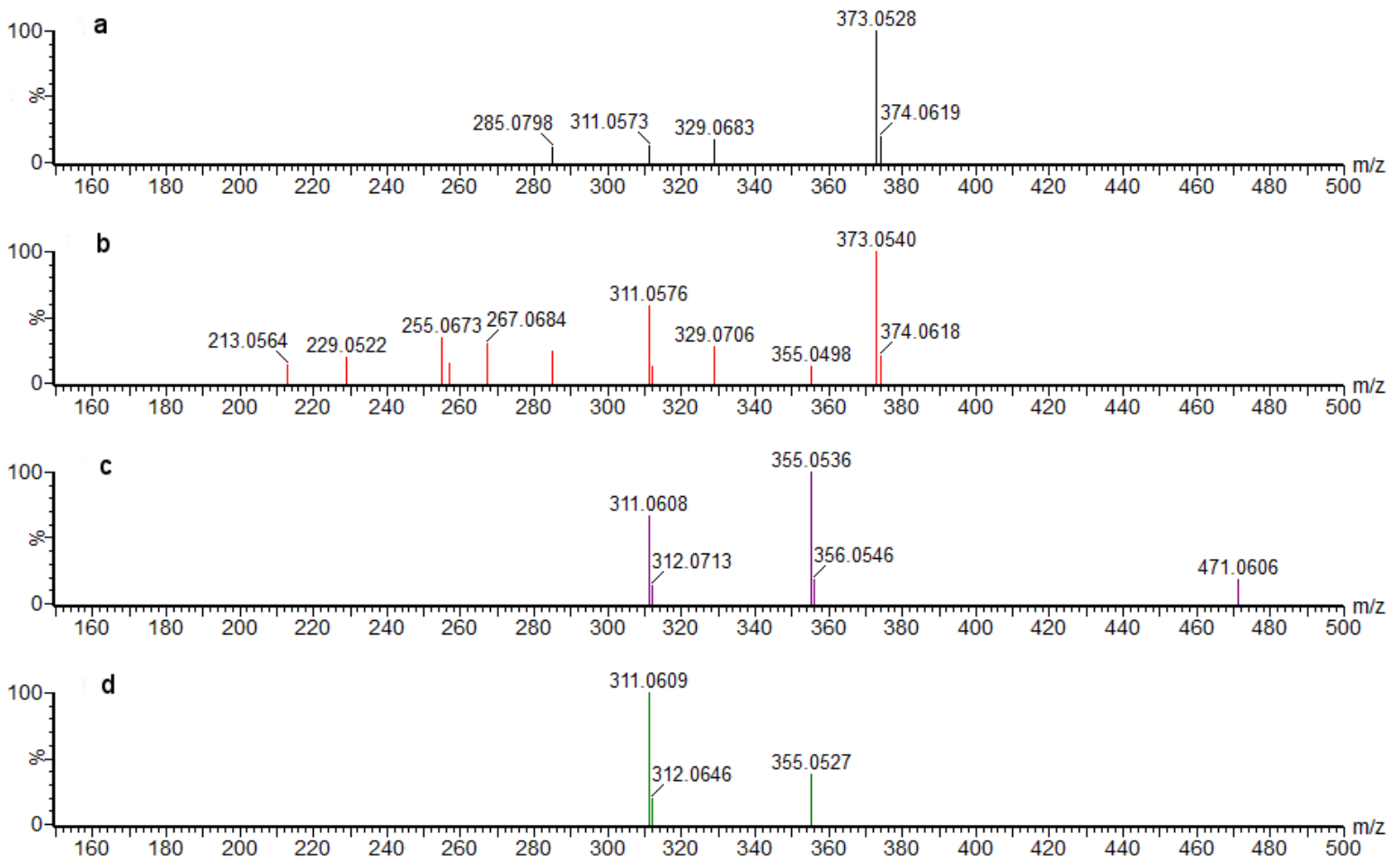

Figure S2. MS spectra of major depsidones in the PD+ Cetraria islandica chemotype.

MS (a) and $\mathrm{MS}^{2}$ (b) spectra for protocetraric acid 1; MS (c) and $\mathrm{MS}^{2}$ (d) spectra for fumarprotocetraric acid 3. 

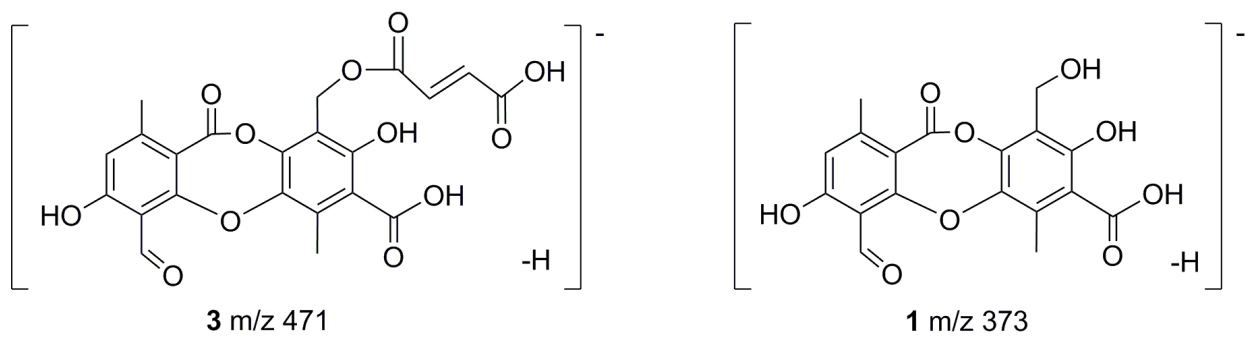<smiles>C=C1C(=O)C(C(=O)O)=C(C)C(Oc2c(C=O)c(O)cc(C)c2C(=O)O)=C1C(=O)O</smiles><smiles>Cc1cc(O)c(C=O)c2c1Oc1c(C)cc(O)c(CO)c1C(=O)O2</smiles><smiles>C=C1C(=O)C=C(C)C2=C1Oc1c(C=O)c(O)cc(C)c1C(=O)O2</smiles>

$1 \mathrm{~m} / \mathrm{z} 329$<smiles>Cc1cc(O)c(CO)c2c1oc1c(C)c(O)cc(C)c12</smiles><smiles>C=C1C(=O)C=C(C)C2=C1C1=C(C)C(=O)C=C(C)C12OC(C)=O</smiles>

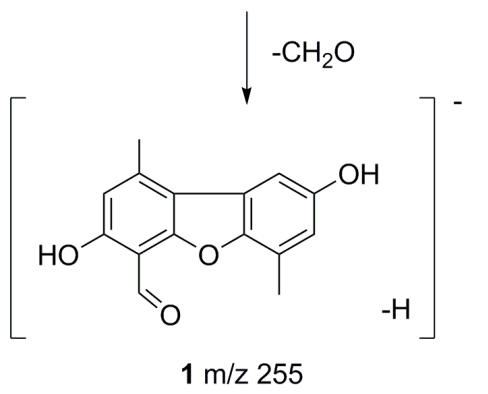

Figure S3. MS fragmentation patterns for major depsidones (protocetraric acid 1; fumarprotocetraric acid 3) in the PD+Cetraria islandica chemotype. 

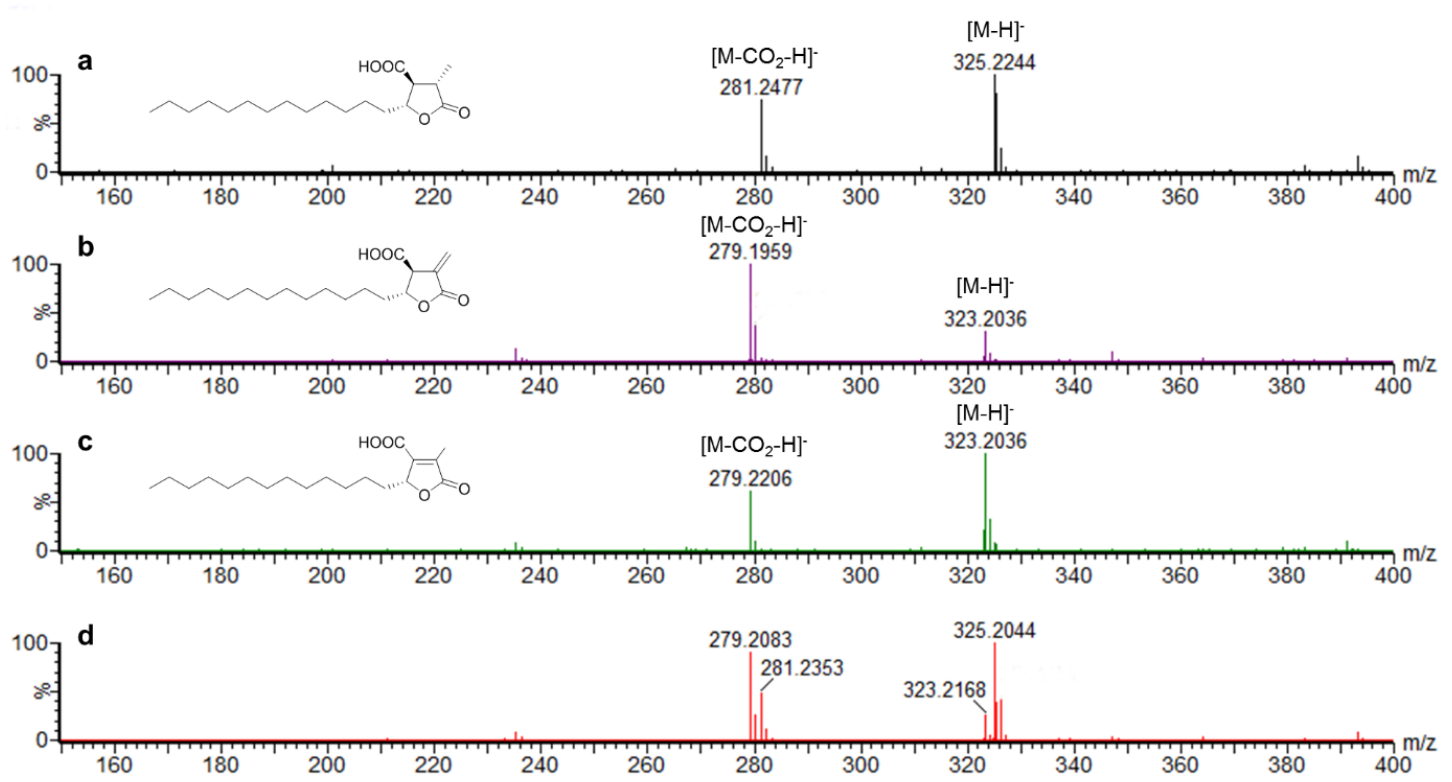

Figure S4. MS spectra for major paraconic acids in Cetraria islandica species complex.

(a) MS spectrum of (+)-roccellaric acid 6; (b) MS spectrum of (+)-protolichesterinic acid 7;

(c) MS spectrum of (+)-lichesterinic acid 8. MS fragment ions of compounds $\mathbf{7}$ and $\mathbf{8}$ differed in the ratio of molecular ion $[\mathrm{M}-\mathrm{H}]^{-}$to the decarboxylated molecular ion $\left[\mathrm{M}-\mathrm{CO}_{2}-\mathrm{H}\right]^{-}$. The higher stability of lichesterinic acid molecular ion could be explained by hyperconjugation, where the electrons in the $\mathrm{C}-\mathrm{C}$ bond between lactone ring and carboxylic group interacts with the unhybridized $p$-orbital in the adjacent ethylenic carbon; (d) MS spectrum of the peak eluting out at $t_{R} 5.87$ min containing two compounds 6A and 7A in Fig 3. They are tentatively identified as a stereoisomer (compound $\mathbf{6 A} ; \mathrm{m} / \mathrm{z} 325.2$ and 281.2) of $\mathbf{6}$ and a stereoisomer (compound $\mathbf{7 A} ; \mathrm{m} / \mathrm{z} 323.2$ and 279.2 ) of $\mathbf{7}$, respectively. 
Table S1. Voucher specimens of Cetraria islandica species complex used in the current study, including country, collection date, voucher number, spot test results/chemotype, DNA isolate number and GenBank accession numbers.

\begin{tabular}{|c|c|c|c|c|c|c|c|}
\hline \multirow{2}{*}{ Country $^{\mathrm{a}}$} & \multirow{2}{*}{ Collection date } & \multirow{2}{*}{ Specimen voucher ${ }^{\mathrm{b}}$} & \multirow{2}{*}{ Spot test ${ }^{\mathrm{c}}$} & \multirow{2}{*}{ Collector } & \multirow{2}{*}{ DNA Isolate } & \multicolumn{2}{|c|}{ GenBank accession number } \\
\hline & & & & & & RPB2 & nrITS \\
\hline \multicolumn{8}{|l|}{ Cetraria islandica } \\
\hline Iceland: IVe & 21-Aug-2012 & LA31863 & $\mathrm{PD}+$ & Starri Heidmarsson & CI1 & KY768945 & KY764967 \\
\hline Iceland: IAu & 16-Aug-2012 & LA31864 & $\mathrm{PD}+$ & Starri Heidmarsson & CI4 & KY768946 & KY764968 \\
\hline Iceland: INo & 21-Aug-2012 & LA31865 & $\mathrm{PD}+$ & Starri Heidmarsson & CI6 & KY768947 & KY764969 \\
\hline Iceland: IVe & 23-Aug-2012 & LA31866 & $\mathrm{PD}+$ & Starri Heidmarsson & $\mathrm{CI} 7$ & KY768948 & KY764970 \\
\hline Iceland: INo & 8-Jul-2013 & LA31867 & PD- & Starri Heidmarsson & CI11 & KY768949 & KY764971 \\
\hline Iceland: IVe & 23-Jul-2013 & LA31868 & $\mathrm{PD}+$ & Starri Heidmarsson & $\mathrm{CI} 12$ & KY768950 & KY764972 \\
\hline Iceland: IVe & 25-Jul-2013 & LA31869 & $\mathrm{PD}+$ & Starri Heidmarsson & CI13 & KY768951 & KY764973 \\
\hline Iceland: IVe & 25-Jul-2013 & LA31870 & $\mathrm{PD}+$ & Starri Heidmarsson & CI14 & KY768952 & KY764974 \\
\hline Iceland: INo & 16-Aug-2012 & LA31871 & $\mathrm{PD}+$ & Starri Heidmarsson & CI15 & KY768953 & KY764975 \\
\hline Iceland: ISu & 12-Jul-2013 & LA31872 & $\mathrm{PD}+$ & Starri Heidmarsson & CI16 & KY768954 & KY764976 \\
\hline Iceland: IVe & 11-Jul-2013 & LA31873 & $\mathrm{PD}+$ & Starri Heidmarsson & CI17 & KY768955 & KY764977 \\
\hline Iceland: IVe & 11-Jul-2013 & LA31874 & $\mathrm{PD}+$ & Starri Heidmarsson & CI18 & KY768956 & KY764978 \\
\hline Iceland: IVe & 9-Aug-2013 & LA31876 & $\mathrm{PD}+$ & Starri Heidmarsson & CI25 & KY768958 & KY764980 \\
\hline Iceland: IVe & 23-Jul-2013 & LA31877 & $\mathrm{PD}+$ & Starri Heidmarsson & CI26 & KY768959 & KY764981 \\
\hline Iceland: IVe & 8-Jul-2013 & LA31878 & $\mathrm{PD}+$ & Starri Heidmarsson & CI27 & KY768960 & KY764982 \\
\hline Iceland: IVe & 8-Jul-2013 & LA31879 & $\mathrm{PD}+$ & Starri Heidmarsson & CI28 & KY768961 & KY764983 \\
\hline Iceland: IVe & 11-Jul-2013 & LA31880 & $\mathrm{PD}+$ & Starri Heidmarsson & CI29 & KY768962 & KY764984 \\
\hline Iceland: IVe & 8-Jul-2013 & LA31881 & $\mathrm{PD}+$ & Starri Heidmarsson & CI30 & KY768963 & KY764985 \\
\hline Iceland: IVe & 21-Aug-2013 & LA31882 & $\mathrm{PD}+$ & Starri Heidmarsson & CI31 & KY768964 & KY764986 \\
\hline Iceland: IVe & 8-Jul-2013 & LA31883 & $\mathrm{PD}+$ & Starri Heidmarsson & CI32 & KY768965 & KY764987 \\
\hline Iceland: INo & 24-Jul-2012 & LA31884 & PD- & Starri Heidmarsson & CI57a & KY768966 & KY764988 \\
\hline Iceland: INo & 24-Jul-2012 & LA31885 & PD- & Starri Heidmarsson & $\mathrm{CI} 57 \mathrm{~b}$ & KY768967 & KY764989 \\
\hline Iceland: INv & 30-Aug-2013 & LA31886 & $\mathrm{PD}+$ & Starri Heidmarsson & CI58 & KY768968 & KY764990 \\
\hline Iceland: IAu & 15-Aug-2012 & LA31887 & $\mathrm{PD}+$ & Starri Heidmarsson & CI59 & KY768969 & KY764991 \\
\hline
\end{tabular}




\begin{tabular}{|c|c|c|c|c|c|c|c|}
\hline Iceland: INv & 22-Aug-2013 & LA31888 & PD- & Starri Heidmarsson & CI60 & KY768970 & KY764992 \\
\hline Iceland: INv & 26-Aug-2013 & LA31889 & PD- & Starri Heidmarsson & CI61 & KY768971 & KY764993 \\
\hline Iceland: INo & 14-Aug-2012 & LA31890 & $\mathrm{PD}+$ & Starri Heidmarsson & CI62 & KY768972 & KY764994 \\
\hline Iceland: IVe & 15-Aug-2012 & LA31928 & $\mathrm{PD}+$ & Starri Heidmarsson & CI63 & KY768973 & KY764995 \\
\hline Iceland: INo & 21-Aug-2012 & LA31891 & $\mathrm{PD}+$ & Starri Heidmarsson & CI64 & KY768974 & KY764996 \\
\hline Iceland: INo & 28-Jun-2012 & LA31929 & PD- & Starri Heidmarsson & CI65 & KY768975 & KY764997 \\
\hline Iceland: IVe & 12-Jul-2013 & LA31892 & $\mathrm{PD}+$ & Starri Heidmarsson & CI66 & KY768976 & KY764998 \\
\hline Iceland: INv & 22-Aug-2013 & LA31893 & PD- & Starri Heidmarsson & CI67 & KY768977 & KY764999 \\
\hline Iceland: INo & 24-Jun-2012 & LA31894 & $\mathrm{PD}+$ & Starri Heidmarsson & CI68 & KY768978 & KY765000 \\
\hline Iceland: INo & 2012 & LA31895 & PD- & Starri Heidmarsson & CI69 & KY768979 & KY765001 \\
\hline Iceland: INo & 2012 & LA31896 & PD- & Starri Heidmarsson & CI70 & KY768980 & KY765002 \\
\hline Iceland: INo & 8-Aug-2012 & LA31897 & $\mathrm{PD}+$ & Starri Heidmarsson & CI77 & KY768981 & KY765003 \\
\hline Iceland: INo & 28-Jun-2012 & LA31898 & $\mathrm{PD}+$ & Starri Heidmarsson & CI78a & KY768982 & KY765004 \\
\hline Iceland: INo & 28-Jun-2012 & LA31899 & $\mathrm{PD}+$ & Starri Heidmarsson & $\mathrm{CI} 78 \mathrm{~b}$ & KY768983 & KY765005 \\
\hline Iceland: INo & 23-Aug-2012 & LA31927 & PD- & Starri Heidmarsson & $\mathrm{CI} 87 \mathrm{a}$ & KY768984 & KY765006 \\
\hline Iceland: INo & 11-Jul-2002 & LA30017 & PD- & Hordur Kristinsson & CI115 & KY768985 & KY765007 \\
\hline Iceland: INo & 14-Aug-2012 & LA31900 & PD- & Starri Heidmarsson & CI117a & KY768986 & KY765008 \\
\hline Iceland: INo & 10-Aug-2006 & LA31128 & PD- & Hordur Kristinsson & CI113 & - & - \\
\hline Iceland: INo & 10-Jul-1998 & LA17549 & PD- & Hordur Kristinsson & CI36 & - & - \\
\hline Iceland: INo & 5-Jul-1998 & LA17221 & PD- & Hordur Kristinsson & CI37 & - & - \\
\hline \multicolumn{8}{|l|}{ etraria ericetorum } \\
\hline Iceland:IAu & 10-Aug-1997 & LA18976 & PD- & Hordur Kristinsson & CE1 & - & KY765009 \\
\hline Finland: Sodankylä & 21-Aug-2003 & NO2530 & PD- & Beata Krewicka & CE6 & KY768987 & KY765010 \\
\hline Sweden: Uppsala & 20-May-2002 & NO23002 & PD- & Leif Tibell & CE8 & KY768988 & KY765011 \\
\hline Sweden: Uppsala & 18-Oct-2015 & NO5626 & PD- & Stefan Ekman & CE11 & KY768989 & KY765012 \\
\hline Iceland: IAu & 13-Jul-2014 & LA20746 & PD- & Hordur Kristinsson & CE13 & KY768990 & KY765013 \\
\hline Iceland: INo & 29-Aug-2016 & LA31901 & PD- & Hordur Kristinsson & CE15 & KY768991 & KY765014 \\
\hline Iceland: INo & 1-Sep-2010 & LA31538 & PD- & Hordur Kristinsson & CE16 & KY768992 & KY765015 \\
\hline Iceland: IAu & 9-Aug-1997 & LA27354 & PD- & Hordur Kristinsson & CE2 & - & - \\
\hline
\end{tabular}




\begin{tabular}{|c|c|c|c|c|c|c|c|}
\hline Sweden: Gävleborg & 15-Jun-1997 & NO501 & PD- & Ake Agren & CE3 & - & - \\
\hline Russian: Komi & 6-Jul-2000 & L135019 & PD- & - & CE4 & - & - \\
\hline Canada: Quebec & 2-Jul-1999 & NO5021 & PD- & Jan-Eric Mattsson & CE5 & - & - \\
\hline Poland: Silesia & 19-Jul-1998 & KO2101 & PD- & - & CE7 & - & - \\
\hline Russia: Komi & 2-Jul-1997 & NO7971 & PD- & Björn Larsson & CE9 & - & - \\
\hline Iceland: INo & 31-Jul-1996 & NO720 & PD- & Starri Heidmarsson & CE10 & - & - \\
\hline Iceland: INo & 18-Aug-1998 & LA20809 & PD- & Hordur Kristinsson & CE12 & - & - \\
\hline Iceland: INo & 19-Aug-1998 & LA29284 & PD- & Hordur Kristinsson & CE17 & - & - \\
\hline Iceland: INo & 10-Aug-1997 & LA18982 & PD- & Hordur Kristinsson & CE18 & - & - \\
\hline
\end{tabular}

${ }^{a}$ INo, INv, IVe, IMi, IAu and ISu refer to corresponding area in Icelandic map below;

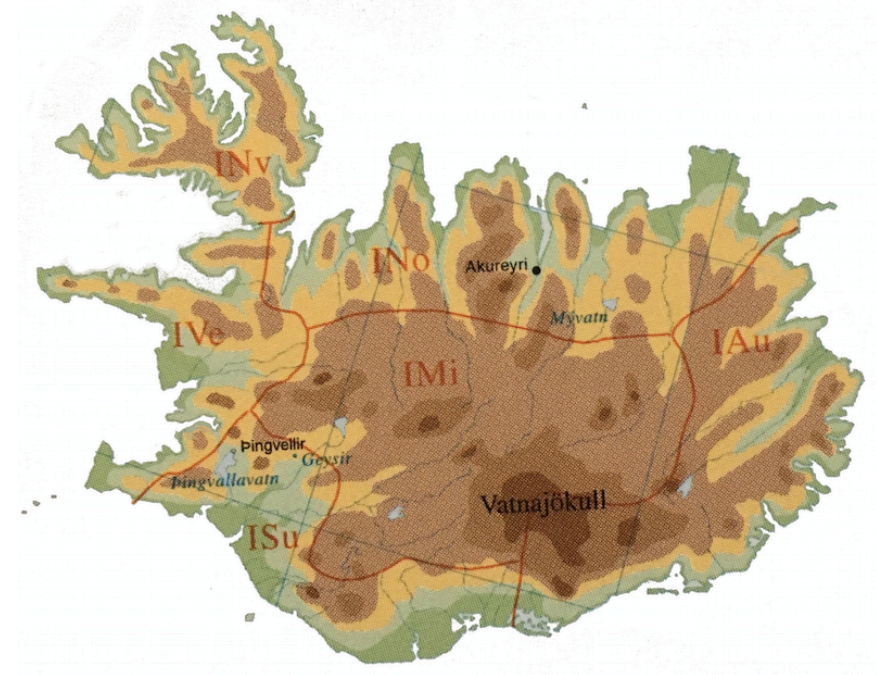

${ }^{\mathrm{b}}$ Authentic herbarium specimens are marked in boldface;

${ }^{c}$ Spot testing/chemotype identification results are reported as PD+ (medullary red color after $p$-phenylendiamine staining) and PD- (no red color after $p$-phenylendiamine staining). 
Table S2. Chromatographic and MS data of metabolites tentatively identified from acetone extracts of taxa in the Cetraria islandica species complex.

\begin{tabular}{|c|c|c|c|c|c|c|}
\hline $\begin{array}{c}t_{R} \\
(\mathrm{~min})^{\mathrm{a}}\end{array}$ & $\begin{array}{c}{[\mathrm{M}-\mathrm{H}]^{-}} \\
(\mathrm{m} / \mathrm{z})^{\mathrm{b}}\end{array}$ & Product ions $(\mathrm{m} / \mathrm{z})^{\mathrm{c}}$ & $\begin{array}{c}\text { Mass error } \\
(\mathrm{ppm})^{\mathrm{d}}\end{array}$ & $\begin{array}{l}\text { Molecular } \\
\text { formula }\end{array}$ & Compound $^{\mathrm{e}}$ & Lichen $^{\mathrm{f}}$ \\
\hline 2.48 & 373.0540 & $355.0498,329.0706,311.0576,285.0798$ & -5.4 & $\mathrm{C}_{18} \mathrm{H}_{14} \mathrm{O}_{9}$ & Protocetraric acid $\mathbf{1}$ & $\mathrm{CI}(\mathrm{PD}+)$ \\
\hline 2.55 & 385.0650 & $341.0783, \mathbf{3 2 9 . 2 4 0 8}$ & - & - & Unidentified & $\mathrm{CE}$ \\
\hline 2.67 & 487.0986 & $373.0665, \mathbf{3 5 5 . 0 5 0 1}, 311.0594$ & - & - & Unidentified & $\mathrm{CI}(\mathrm{PD}+)$ \\
\hline 2.75 & 473.0806 & 355.0451, 311.0550 & -0.8 & $\mathrm{C}_{22} \mathrm{H}_{18} \mathrm{O}_{12}$ & Succinprotocetraric acid 2 & $\mathrm{CI}(\mathrm{PD}+)$ \\
\hline 2.88 & 517.1052 & $401.0900,369.0647,325.0730$ & 6.7 & - & Unidentified & $\mathrm{CI}(\mathrm{PD}+)$ \\
\hline 2.96 & 471.0536 & 355.0467, 311.0581 & -1.4 & $\mathrm{C}_{22} \mathrm{H}_{16} \mathrm{O}_{12}$ & Fumarprotocetraric acid $\mathbf{3}$ & $\mathrm{CI}(\mathrm{PD}+)$ \\
\hline 3.07 & 489.3547 & $355.0500, \mathbf{3 4 3 . 0 4 7 4}, 311.0598,299,0618$ & - & - & Unidentified & $\mathrm{CI}(\mathrm{PD}+)$ \\
\hline 3.17 & 387.0728 & $355.0474,343.0864,311.0580,299.0962$ & 3.1 & $\mathrm{C}_{19} \mathrm{H}_{16} \mathrm{O}_{9}$ & Unidentified & $\mathrm{CI}(\mathrm{PD}+)$ \\
\hline 3.21 & 293.1744 & $236.1066,221.1552$ & -3.1 & $\mathrm{C}_{17} \mathrm{H}_{26} \mathrm{O}_{4}$ & Unidentified & CI, CE \\
\hline 3.34 & 431.3405 & $355.0503,309.1720$ & 7.4 & $\mathrm{C}_{24} \mathrm{H}_{48} \mathrm{O}_{6}$ & Unidentified & $\mathrm{CI}(\mathrm{PD}+)$ \\
\hline 3.57 & 357.0607 & $313.0723,269.0848$ & -0.8 & $\mathrm{C}_{18} \mathrm{H}_{14} \mathrm{O}_{8}$ & Virensic acid 4 & $\mathrm{CI}(\mathrm{PD}+)$ \\
\hline 4.17 & 295.2257 & $277.2194,171.1052$ & -5.4 & $\mathrm{C}_{18} \mathrm{H}_{32} \mathrm{O}_{3}$ & Unidentified & $\mathrm{CE}$ \\
\hline 4.71 & - & $443.3083, \mathbf{2 7 9 . 2 3 1 0}, 250.1470$ & -5.0 & - & Unidentified & $\mathrm{CI}, \mathrm{CE}$ \\
\hline 4.94 & - & $297.2133, \mathbf{2 7 9 . 2 3 8 3}, 264.1647,253.2214$ & - & - & Unidentified & $\mathrm{CI}, \mathrm{CE}$ \\
\hline 5.03 & 279.2364 & 251.2069 & - & - & Unidentified & $\mathrm{CI}, \mathrm{CE}$ \\
\hline 5.09 & 295.1935 & 251.2062 & 8.8 & $\mathrm{C}_{17} \mathrm{H}_{28} \mathrm{O}_{4}$ & Nephrosterinic acid $\mathbf{5}$ & $\mathrm{CI}, \mathrm{CE}$ \\
\hline 5.44 & - & $311.2299, \mathbf{2 8 1 . 2 5 5 6}$ & - & - & Unidentified & $\mathrm{CI}, \mathrm{CE}$ \\
\hline 5.77 & 323.2168 & 279.2314 & -3.6 & $\mathrm{C}_{19} \mathrm{H}_{32} \mathrm{O}_{4}$ & A stereoisomer of (+)-Protolichesterinic acid $\mathbf{7 A}$ & $\mathrm{CI}, \mathrm{CE}$ \\
\hline 5.77 & 325.2370 & 281.2527 & -2.8 & $\mathrm{C}_{19} \mathrm{H}_{34} \mathrm{O}_{4}$ & A stereoisomer of (+)-Roccellaric acid $\mathbf{6 A}$ & $\mathrm{CE}$ \\
\hline 6.05 & 325.2405 & 281.2511 & 8.0 & $\mathrm{C}_{19} \mathrm{H}_{34} \mathrm{O}_{4}$ & $(+)$-Roccellaric acid 6 & $\mathrm{CI}, \mathrm{CE}$ \\
\hline 6.17 & 323.2234 & 279.2322 & -0.7 & $\mathrm{C}_{19} \mathrm{H}_{32} \mathrm{O}_{4}$ & $(+)$-Protolichesterinic acid 7 & $\mathrm{CI}, \mathrm{CE}$ \\
\hline 6.23 & 323.2224 & 279.2372 & 0.6 & $\mathrm{C}_{19} \mathrm{H}_{32} \mathrm{O}_{4}$ & Lichesterinic acid 8 & $\mathrm{CI}, \mathrm{CE}$ \\
\hline 6.46 & 323.2218 & 279.2336 & 4.5 & $\mathrm{C}_{19} \mathrm{H}_{32} \mathrm{O}_{4}$ & A stereoisomer of $(+)$-Protolichesterinic acid 7B & $\mathrm{CI}, \mathrm{CE}$ \\
\hline
\end{tabular}

${ }^{\mathrm{a}} \mathrm{t}_{\mathrm{R}}$ means retention time;

${ }^{\mathrm{b}}[\mathrm{M}-\mathrm{H}]^{-}$stands for deprotonated molecular ion;

${ }^{c}$ The product ion is marked in bold when it is the base peak in the MS spectrum;

d The mass error of the base peak is provided;

${ }^{\mathrm{e}}$ Major compounds 1-8 are labelled corresponding to structures in Figure 2;

${ }^{\mathrm{f}}$ The presence of lichen compounds in lichen taxa. CI (PD+): the PD+ chemotype of Cetraria islandica; CI: both PD+ and PD- chemotypes of $C$. islandica; CE: $C$. ericetorum. 